\title{
マグネトロンスパッタリング法による ホウ素含有薄膜の創成とその機械的特性の評価*
}

\author{
一 反応ガス添加の影響 — \\ 神 崎 昌 郎** \\ Preparation of Boron Containing Thin Films by Magnetron Sputtering Method \\ and Evaluation of Their Mechanical Properties \\ - Influences of Reactive Gas Addition -
}

\begin{abstract}
Masao KOHZAKI
Thin films containing boron have been prepared on silicon substrates by DC magnetron sputtering using a sintered boron carbide $\left(\mathrm{B}_{4} \mathrm{C}\right)$ target. The influences of $\mathrm{N}_{2}$ or $\mathrm{H}_{2}$ addition as a reactive gas on chemical bonding states, nano-indentation hardness, adhesive strength to the substrate and the friction coefficient of the films are investigated. Nano-indentation studies show that $\mathrm{N}_{2}$ addition in the film formation process leads to a lower hardness of the film. Absorption spectra in Fourier-transform infrared spectroscopy exhibit peaks corresponding to hexagonal boron nitride, and $\mathrm{C}$ 1s peaks and $\mathrm{N} 1 \mathrm{~s}$ peak in X-ray photoelectron spectroscopy spectra indicate that nitrogen dose not bond to carbon. The lack of a three-dimensional boron-carbon-nitrogen network in the films is thought to be a reason for the deterioration in the nano-indentation hardness of the films. On the other hand, the adhesive strength is increased significantly by $\mathrm{N}_{2}$ or $\mathrm{H}_{2}$ addition in the film formation process, although the frictional properties of the film against a steel ball in an ambient atmosphere are not improved in this study.
\end{abstract}

Key words: boron, B-C-N, mechanical property, magnetron sputtering, reactive gas

\section{1. 緒言}

立方晶 $\mathrm{BN}$ や $\mathrm{B}_{4} \mathrm{C}$ に代表されるホウ素含有材料およびその薄 膜は, 硬度が高く $1000^{\circ} \mathrm{Cを}$ 超える高温においても化学的に安定 である等の優れた特性を有している. 特に, これらの薄膜が鉄 鋼材料の加工に使用可能であることは, ダイヤモンドをはじめ とする炭素系硬質膜にはない優れた特徴である.この特徵を積 極的に活用することにより, 鉄鋼材料が使用されている各種摺 動部品にも広く応用されていくと考えられる 1)2). また, 近年で は立方晶 $\mathrm{BN}$ や $\mathrm{B}_{4} \mathrm{C}$ に加え, ダイヤモンドと同等以上の硬度を 有することが示唆されている $\left.\beta-\mathrm{C}_{3} \mathrm{~N}_{4}{ }^{3) 4}\right)$ も新規硬質材料として注 目されている. さらに, これら各種硬質材料の優れた特性を持 ち合わせる可能性のあるものとして, B-C-N 三元系材料が大き な期待を集めるようになってきた. これらの材料は非常に硬度 が高く脆性的であるということ, およびこれらの材料の主たる 応用先が切削工具・摺動部品になるであろうことを考えた場合, バルク体として形成するよりも薄膜として創成する方が容易か つ適切と判断される. しかし，これまでに多くの研究が行われ てきた立方晶 $\mathrm{BN}$ の成膜においても, 限られた範囲のバイアス 電圧を基板に印加した場合にのみ所望の結晶相が得られる等の 困難が伴うだけではなく 5$) 6, \quad \beta-\mathrm{C}_{3} \mathrm{~N}_{4}$ や B-C-N 三元系材料の創 成においては, 成膜条件と得られた膜の構造, あるいは機械的 特性との関係は必ずしも明らかになっていない778). 特に, 切削 工具や摺動部品に応用する際に必須である基板に対する高い密 着力をどのようにして得るかは大きな課題であり, 実用化を阻

* 原稿受付 平成 17 年 8 月 26 日

** 正 会 員 東海大学 (神奈川県平塚市北金目 1117)
害する要因となっている.

そこで本研究においては，B-C-N 三元系新規硬質材料の創成 を念頭に置き, ホウ素含有薄膜形成時に反応ガスとして $\mathrm{N}_{2}$ ガス あるいは $\mathrm{H}_{2}$ ガスを添加することにより, 組成および化学的結合 状態がどのように変化するかを評価することとした．また，そ の化学的結合状態の変化がホウ素含有薄膜の機械的特性, 特に 密着力に及ぼす影響を調へ，切削工具や摺動部品に応用可能な 新規硬質形成に関する知見を集積することを目指した.

\section{2. 実 験 方 法}

\section{1 ホウ素含有薄膜の形成}

ホウ素含有薄膜の形成は, DC マグネトロンスパッタリング法 により行った. 本実験で用いた装置の概略を図 1 に示す. 反応 チャンバー上部にマグネトロン陰極を配置し, ターゲットには

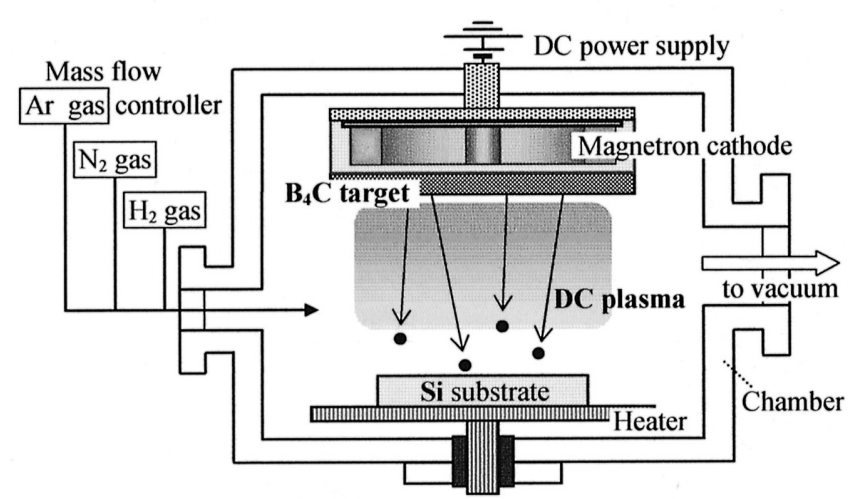

Fig.1 Schematic diagram of DC magnetron sputtering apparatus 
純度 $99 \%$ 以上の $\mathrm{B}_{4} \mathrm{C}$ 焼結体を用いた. また, 基板として $20 \mathrm{~mm}$ 口に切り出した厚さ $0.5 \mathrm{~mm}$ の $\mathrm{Si}$ ウェハを用い，アセトン中で 超音波洗浄し乾燥後, マグネトロン陰極に対向するように反応 チャンバー内に装填した. なお, 今回の実験では基板へのバイ アス電圧印加は行っていない，基板ホルダーを加熱することに より成膜時の基板温度を $150^{\circ} \mathrm{C}, 250^{\circ} \mathrm{C}$ に制御し, 加熱しない場 合の基板の温度は $50^{\circ} \mathrm{C}$ 以下であることを確認した. ターボ分子 ポンプを用いて反応チャンバー内を $1.0 \times 10^{-3} \mathrm{~Pa}$ まで真空排気し， $\mathrm{Ar}$ ガスを導入した後, 直流電圧を印加しプラズマを発生させた. 本実験においては, 成膜時の $\mathrm{Ar}$ ガス導入量を $25 \mathrm{sccm} に$ に, 投入 電力を $250 \mathrm{~W}$ に固定し, 反応ガスとして $\mathrm{N}_{2}$ ガスあるいは $\mathrm{H}_{2}$ ガ スを添加する場合は, その導入量を $10 \mathrm{sccm}, 25 \mathrm{sccm}$ とした. なお，成膜に用いたガスの純度はいずれも $99.999 \%$ 以上であり， 反応ガスを導入することにより, スパッタリング時の圧力は 0.9 $\sim 2.0 \mathrm{~Pa}$ の範囲で変動した. また, 機械的特性の評価に十分な 膜厚を得るために成膜時間を 60 分間とした.

\section{2 ホウ素含有薄膜の評価}

得られたホウ素含有薄膜 ( $\mathrm{B}_{4} \mathrm{C}$ 系薄膜) の化学結合状態の評 価は, フーリエ変換赤外分光分析 (FT-IR) 法および X 線光電 子分光分析 (XPS) 法により行った. FT-IR 吸収スペクトルは $400 \sim 1800 \mathrm{~cm}^{-1}$ の範囲で測定した. XPS 分析における B 1s, C 1s および N 1s の結合エネルギーの測定は, 表面吸着物の影響を取 り除くため $3 \mathrm{keV}$ の $\mathrm{Ar}$ イオンで 1 分間スパッタクリーニングを した後に行った. また，それぞれの元素の感度係数およびピー クの面積を用いて, 薄膜中の $\mathrm{B}, \mathrm{C}$ および $\mathrm{N}$ の相対的比率を算 出した

なお, 得られたホウ素含有薄膜の結晶化の有無を薄膜 X 線回 折法により評価したが，今回の成膜条件では形成された全ての 薄膜において回折ピークは観測されず，非晶質であることが確 認された.

ホウ素含有薄膜の膜厚の測定は, 成膜時のマスキング部に形 成された段差を触針式表面形状測定器 DEKTAK-IIA を用いて 読み取ることにより行った。 また，超微小押し込み硬さ試験機 （エリオニクス社製 ENT1100a）を用いたナノインデンテーシ ヨン法により荷重一変位曲線を測定した。この曲線の除荷時部 分において, 最大押し込み荷重の $90 \%$ から $50 \%$ を直線近似し, そ の直線と横軸との交点から見積もつた塑性変形量を基に微小硬度 を求めた. 微小硬度の算出には 5 回の測定により得られた荷重 一変位曲線の平均值を用いた. 圧子には三角錐上のダイヤモン ド圧子 (Berkovich 圧子) を用い, 最大押し込み荷重を $0.98 \mathrm{mN}$ とした.

密着力の測定は超薄膜スクラッチ試験機（レスカ社製

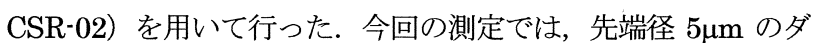
イヤモンド圧子をバネ定数 $108.4 \mathrm{~g} / \mathrm{mm}$ の弾性アームに取り付 け, 試料（ $\mathrm{Si}$ 基板上にホウ素含有薄膜を形成したもの）を設置 するステージの傾斜角を 3 度とした. このステージを $10 \mu \mathrm{m} / \mathrm{s}$ の速度で移動させ，ダイヤモンド圧子がホウ素含有薄膜に接触 することにより生じる押し付け荷重を連続的に増加させた. 薄 膜の剥離に伴う摩擦力等の変化を電気信号の変化として検出し, 剥離に至った荷重を臨界荷重としてホウ素含有薄膜の密着力を 示す指標とした.

摩擦係数の測定は往復摺動式摩擦試験機を用いて室温・大気 中・無潤滑下で行った. 相手材として直径 $5 \mathrm{~mm}$ の SUJ2 ボー ルを用い, 試験荷重を $0.5 \mathrm{~N}$, 摩擦速度を $5 \mathrm{~mm} / \mathrm{s}$, 摩擦回数を 50 回として測定を行った.
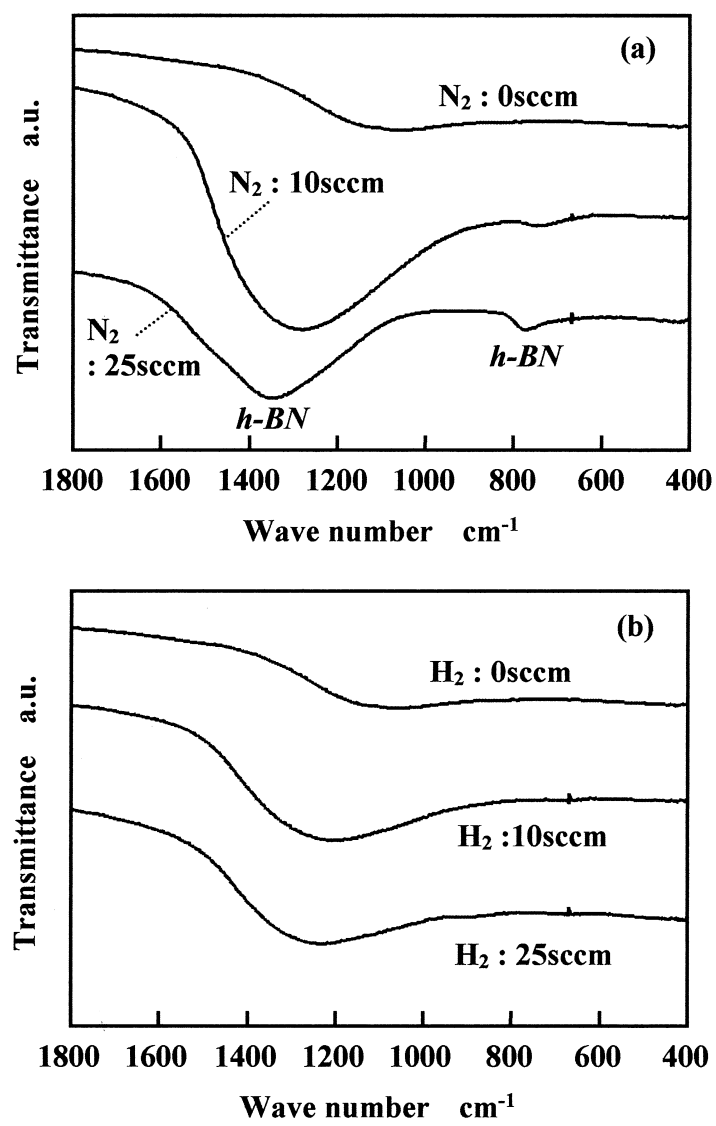

Fig.2 FT-IR spectra obtained from $\mathrm{B}_{4} \mathrm{C}$ films (a) prepared with $\mathrm{N}_{2}$ introduction, (b) with $\mathrm{H}_{2}$ introduction

\section{3. 実験結果および考察}

基板温度を $50^{\circ} \mathrm{C}$ 以下および $150^{\circ} \mathrm{C}$ して形成した薄膜は，成 膜直後から剥離を生じる場合があり， $\mathrm{N}_{2}$ ガスあるいは $\mathrm{H}_{2}$ ガス 導入による機械的特性の系統的変化を評価するに至らなかった. したがって, 以下では成膜後に剥離することがなかった $250^{\circ} \mathrm{C}$ で形成した薄膜の評価結果について述べる.

\section{1 ホウ素含有薄膜の化学結合状態}

図 2 に反応ガス導入に伴うホウ素含有薄膜の FT-IR スペクト ルの変化を示す. $\mathrm{Ar}$ プラズマのみ $\left(\mathrm{N}_{2}: 0 \mathrm{sccm}, \mathrm{H}_{2}: 0 \mathrm{sccm}\right)$ で形成した薄膜の FT-IR スペクトルにおいては，1100〜 $1200 \mathrm{~cm}^{-1}$ 付近にブロードなピークが観測された. これは非晶質 の $\mathrm{B}_{4} \mathrm{C}$ 系薄膜に特徵的なピークであり 9 , 非晶質であることが 確認された前述の薄膜 X 線回折の結果と一致するものである. それに対し， $\mathrm{N}_{2}$ ガスを導入して形成した薄膜においては, 1100 $\sim 1200 \mathrm{~cm}^{-1}$ 付近のブロードなピークが $1380 \mathrm{~cm}^{-1}$ 付近まで高波 数側にシフトするとともに, $780 \mathrm{~cm}^{-1}$ 付近にピークが観測される ようになった（図 2(a)参照）。これらのピークは六方晶 $\mathrm{BN}$ (h-BN) に近い化学的結合が形成されていることを示すもので あり ${ }^{10)}$ ，硬質化に有効である立方晶 $\mathrm{BN}$ のピーク $\left(1080 \mathrm{~cm}^{-1}\right.$ 近 傍 11)）は観測されなかった. 一方， $\mathrm{H}_{2}$ ガスを導入した場合に は，新たな吸収ピークが観測されることはなく基本的には非晶 質 $\mathrm{B}_{4} \mathrm{C}$ 構造を維持していると考えられるが，1100～1200 $\mathrm{cm}^{-1}$ 付近のピークは水素含有に伴う B-C 構造の歪みに対応して高波 数側にシフトした（図 $2(\mathrm{~b})$ 参照）.

$\mathrm{N}_{2}$ ガスおよび $\mathrm{H}_{2}$ ガスの導入量を $25 \mathrm{sccm}$ として形成したホウ 素含有薄膜の XPS B 1s および C 1s スペクトルを図 3 に示す. 

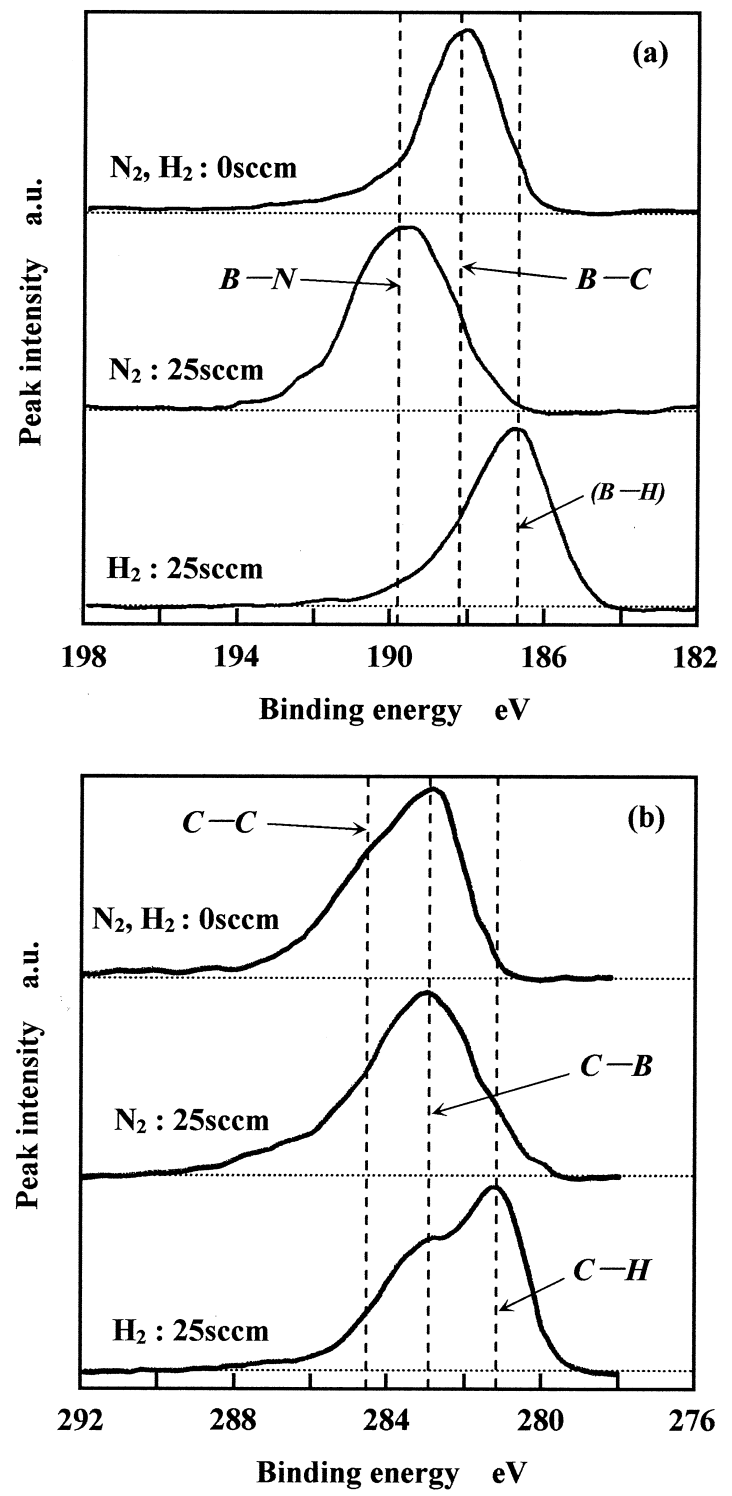

Fig.3 XPS spectra of $\mathrm{B}_{4} \mathrm{C}$ films, (a) B 1s spectra, (b) $\mathrm{C}$ 1s spectra

比較のために, Ar プラズマのみで形成した薄膜の XPS スペク トルを併せて図 3 に示した. 反応ガスを導入せずに形成した薄 膜の B 1s およびC 1s スペクトルにおいては, それぞれ $188.2 \mathrm{eV}$, $282.9 \mathrm{eV}$ を主成分とするピークが観測された. いずれも, $\mathrm{B}_{4} \mathrm{C}$ における B-C 結合に対応するものである ${ }^{12)}$. ただし， C 1s スペ クトルにおいては，高エネルギー側に C-C 結合に対応する $284.5 \mathrm{eV}$ 付近をピークとする成分が含まれていた. したがって, この C-C 結合の生成に伴い, 余剰のホウ素が形成する B-B 結合 の成分が $188 \mathrm{eV}$ 付近の B 1s ピークに含まれると考えられる 13). 一方, $\mathrm{N}_{2}$ ガスを導入して形成した薄膜においては， $190 \mathrm{eV}$ 付近 に B-N 結合を示す B1s ピークが観測された ${ }^{14)}$.また， C 1s ス ペクトルにおいては, C-N 結合の存在を示す $286 \mathrm{eV}$ 近傍のピー ク7は明確には観測されなかった. 今回測定した N 1s スペクト ルにおいて， $398 \mathrm{eV}$ にホウ素との結合を示すシャープなシング ルピークが存在したこと，および上述の FT-IR の結果を考え合 わせると，添加した窒素はほとんどすべて h-BN に近い結合状 態を有して存在していると判断される．また， $\mathrm{H}_{2}$ ガスを導入し て形成した薄膜においては， B 1s および C 1s いずれのピーク も低エネルギー側にシフトしており，水素との結合が影響して
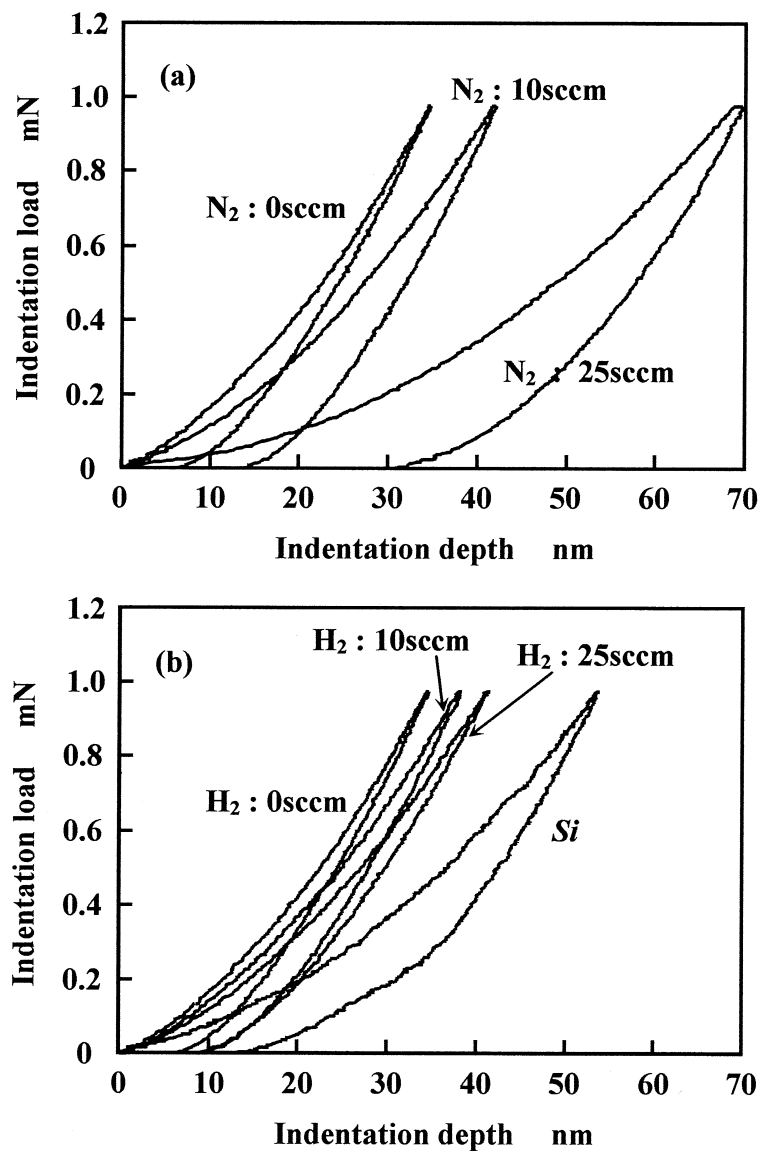

Fig.4 Nano-indentation load vs. indentation depth curves obtained from Si substrate and $\mathrm{B}_{4} \mathrm{C}$ films (a) prepared with $\mathrm{N}_{2}$ introduction, (b) with $\mathrm{H}_{2}$ introduction

いるものと推測される.

なお, XPS スペクトルから求めた $\mathrm{B}, \mathrm{C}$ および $\mathrm{N}$ の相対的比 率 $(\mathrm{B}: \mathrm{C}: \mathrm{N})$ は, $\mathrm{Ar}$ プラズマのみで形成した薄膜および $\mathrm{H}_{2}$ ガス導入量を $25 \mathrm{sccm}$ として形成した薄膜において，それぞれ $1.0: 0.32: 0.03,1.0: 0.36: 0.09$ であり, 若干炭素量が多いも のの $\mathrm{B}_{4} \mathrm{C}$ 組成に近いものであった. それに対し, $\mathrm{N}_{2}$ ガス導入量 を $25 \mathrm{sccm}$ とした場合の相対比率は $1.0: 0.68: 0.66$ であり, $\mathrm{N}_{2}$ ガス導入に伴い膜中に取り込まれる炭素が増える傾向にあっ た.

\section{2 木ウ素含有薄膜の微小硬度}

ナノインデンテーション法により得られたホウ素含有薄膜上 の荷重一変位曲線を図 4 に示寸. また, その荷重一変位曲線を 用いて算出した各薄膜の微小硬度を表 1 および図 5 に示す. Ar プラズマでのみ形成した薄膜上の最大押し込み深さは $35 \mathrm{~nm}$, また, それを基に算出した微小硬度は $31 \mathrm{GPa}$ と比較的高硬度で あった. それに対し, 成膜時に $\mathrm{N}_{2}$ ガスあるいは $\mathrm{H}_{2}$ ガスを導入 することにより, また, その導入量を増やすことにより, 最大 押し込み深さは増大し, 微小硬度は低下した（表 1 および図 4 参照). 特に, $\mathrm{N}_{2}$ ガス導入量を $25 \mathrm{sccm}$ とした場合に得られた薄 膜の最大押し込み染さは $70 \mathrm{~nm}$ にも及び, 他の条件で成膜した 薄膜における最大押し込み深さの 2 倍程度であった（図 4(a)参 照)。また，この条件で成膜した微小硬度は 8GPa であり， $\mathrm{Si}$ 基板の微小硬度（13GPa）より小さい值であった. これは, 先 に述べたように今回の成膜条件においては, 導入した窒素が立 方晶 BNに近い構造の形成あるいは B-C-N 三次元構造の形成に 
Table 1 Nano-indentation hardness of $\mathrm{B}_{4} \mathrm{C}$ films

\begin{tabular}{|c|c|c|}
\hline $\begin{array}{l}\text { Additive amount of } \\
\mathrm{N}_{2} \text { or } \mathrm{H}_{2} \text { gas }\end{array}$ & Film thickness & $\begin{array}{c}\text { Nano-indentation } \\
\text { hardness }\end{array}$ \\
\hline 0 & $450 \mathrm{~nm}$ & $31 \mathrm{GPa}$ \\
\hline $\mathrm{N}_{2} \quad 10 \mathrm{sccm}$ & $450 \mathrm{~nm}$ & $21 \mathrm{GPa}$ \\
\hline $\mathrm{N}_{2} 25 \mathrm{sccm}$ & $300 \mathrm{~nm}$ & $8 \mathrm{GPa}$ \\
\hline $\mathrm{H}_{2} \quad 10 \mathrm{sccm}$ & $400 \mathrm{~nm}$ & $25 \mathrm{GPa}$ \\
\hline $\mathrm{H}_{2} 25 \mathrm{sccm}$ & $400 \mathrm{~nm}$ & $21 \mathrm{GPa}$ \\
\hline \multicolumn{2}{|c|}{ Si substrate } & $13 \mathrm{GPa}$ \\
\hline
\end{tabular}

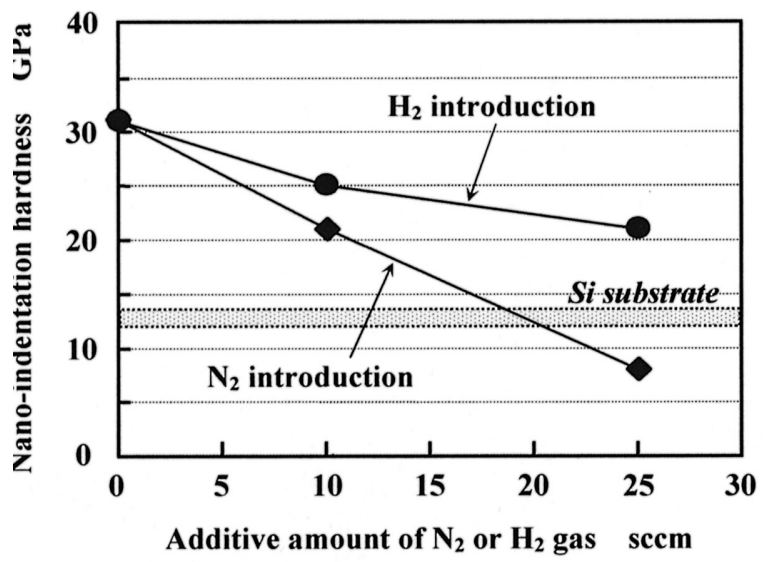

Fig.5 Nano-indentation hardness of $\mathrm{B}_{4} \mathrm{C}$ films as a function of additive amount of $\mathrm{N}_{2}$ or $\mathrm{H}_{2}$ gas

寄与せず，二次元的層状構造である $\mathrm{h}-\mathrm{BN}$ を構成していること に対応する結果と考えられる. それに対し， $\mathrm{H}_{2}$ ガスを導入した 場合には, その導入量を $25 \mathrm{sccm}$ として形成した薄膜において も微小硬度は $21 \mathrm{GPa}$ であり, 硬度低下の度合いは小さかった. これは, 図 2(b)に示した FT-IR スペクトルに観られるように, 膜中に水素が含まれ構造に歪が生じるものの, 基本的には $\mathrm{B}_{4} \mathrm{C}$ に近い化学的結合状態を維持しているためと推測される.

なお, 今回形成した薄膜の厚さは $400 \mathrm{~nm}$ 程度であり, $\mathrm{N}_{2} カ ゙$ ス導入量を $25 \mathrm{sccm}$ として形成した薄膜を除けば，各薄膜にお

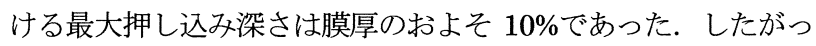
て，今回測定された微小硬度には $\mathrm{Si}$ 基板の影響はほとんどない と考えられる.

\section{3 ホウ素含有薄膜の密着力}

図 6 にホウ素含有薄膜のスクラッチ特性を示す.Ar プラズマ のみで形成した薄膜においては，薄膜の剥離を示寸臨界荷重は $20 \mathrm{mN}$ 程度であるのに対し， $\mathrm{N}_{2}$ ガスを $25 \mathrm{sccm}$ 導入することに より臨界荷重は $120 \mathrm{mN}$ 以上と著しく大きくなった. この臨界 荷重の反応ガス導入量依存性を示したのが図 7 である. $\mathrm{N}_{2}$ ガス を導入した場合と同様, $\mathrm{H}_{2}$ ガスを導入した場合も臨界荷重は増 大した. 程度の差はあるものの, 図 5 に示したようにいずれの 反応ガスを導入した場合も微小硬度は低下しており，この硬度 低下に伴う膜中の内部応力の緩和が密着力（臨界荷重）増大の 一因であると考えられる. ただし， $\mathrm{H}_{2}$ ガスを導入した場合の木 ウ素含有薄膜の硬度低下は小さいにもかかわらず, $\mathrm{N}_{2}$ ガスを導 入した場合に近い密着力向上の効果が得られたことから, $\mathrm{H}_{2}$ ガスの還元作用による基板表面の酸化物除去等も密着力向上の

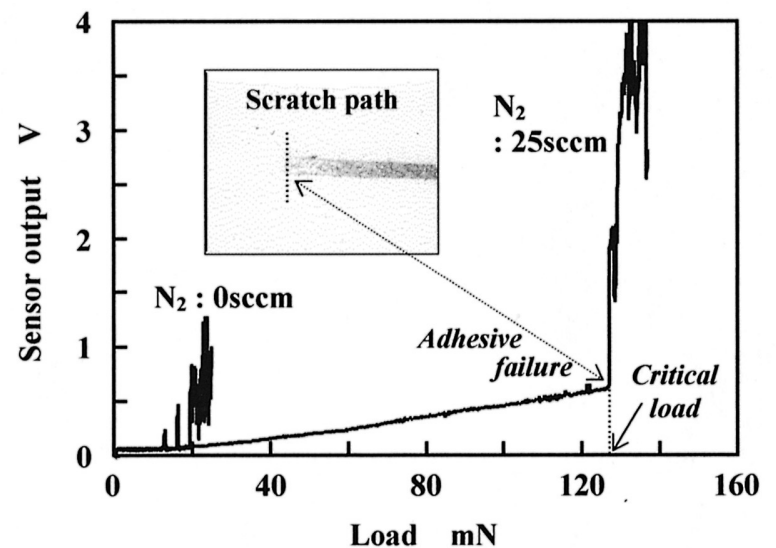

Fig.6 Scratch properties of $\mathrm{B}_{4} \mathrm{C}$ films

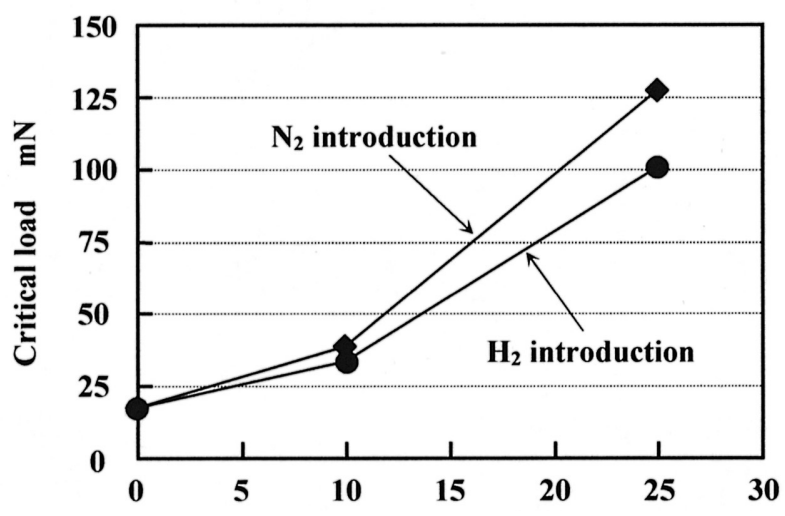

Additive amount of $\mathrm{N}_{2}$ or $\mathrm{H}_{2}$ gas scem

Fig.7 Critical loads for $\mathrm{B}_{4} \mathrm{C}$ films in scratch tests as a function of additive amount of $\mathrm{N}_{2}$ or $\mathrm{H}_{2}$ gas

機構として作用していると推測される.

\section{4 ホウ素含有薄膜の摩擦特性}

図 8 に $\mathrm{N}_{2}$ ガスあるいは $\mathrm{H}_{2}$ ガスを導入して形成したホウ素含 有薄膜の室温・大気中・無潤滑下での摩擦係数を示す. SUJ2 ボールと Si の摩擦係数は 1.0 程度であるのに対し, Ar プラズマ でのみ形成した薄膜および $\mathrm{N}_{2}$ ガスを $10 \mathrm{sccm}$ 導入して形成した 薄膜の摩擦係数は 1.0 を大きく超えた值となった. 先に述べた ように，これらの薄膜は基板に対する密着力が低く，摩擦試験 中に剥離し, その一部が摺動界面に存在したため摩擦特性が悪 化したと考えられる. また, $\mathrm{N}_{2}$ ガス導入量を $25 \mathrm{sccm}$ として形 成した薄膜は硬度が低下したものの密着力が向上し, 摩擦試験 時の剥離は僅かであったが, 摩擦係数は $\mathrm{Si}$ と同程度 1.0 程度で あった (図 8 (a)参照). $\mathrm{N}_{2}$ ガスの導入量を $25 \mathrm{sccm}$ とすることに より，層状構造を有する h-BN に近い結合が形成されたが，そ の配向状態が必ずしも摩擦方向と一致していなかったため, 低 摩擦化の効果が得られなかったと考えられる. また, 図 $8(\mathrm{~b})$ に 示したように $\mathrm{H}_{2}$ ガスを導入して形成した薄膜においても, 摩擦 係数低減の効果は観測されなかった. $\mathrm{H}_{2}$ ガスを $10 \mathrm{sccm}$ 導入し て形成した薄膜を同量の $\mathrm{N}_{2}$ ガス導入により得られた薄膜と比 較した場合, 密着力はほぼ同程度であったが, 硬度が $4 \mathrm{GPa}$ 大 きかった (表 1 参照)。このため摩擦試験時の剥離の程度が抑制 され, 摩擦係数が増大することはなかったと考えられる.さら に $\mathrm{H}_{2}$ ガス導入量を増やして形成した薄膜においては, 高硬度特 性を維持したまま密着力が大きく上昇したが, 密着力自体はま 

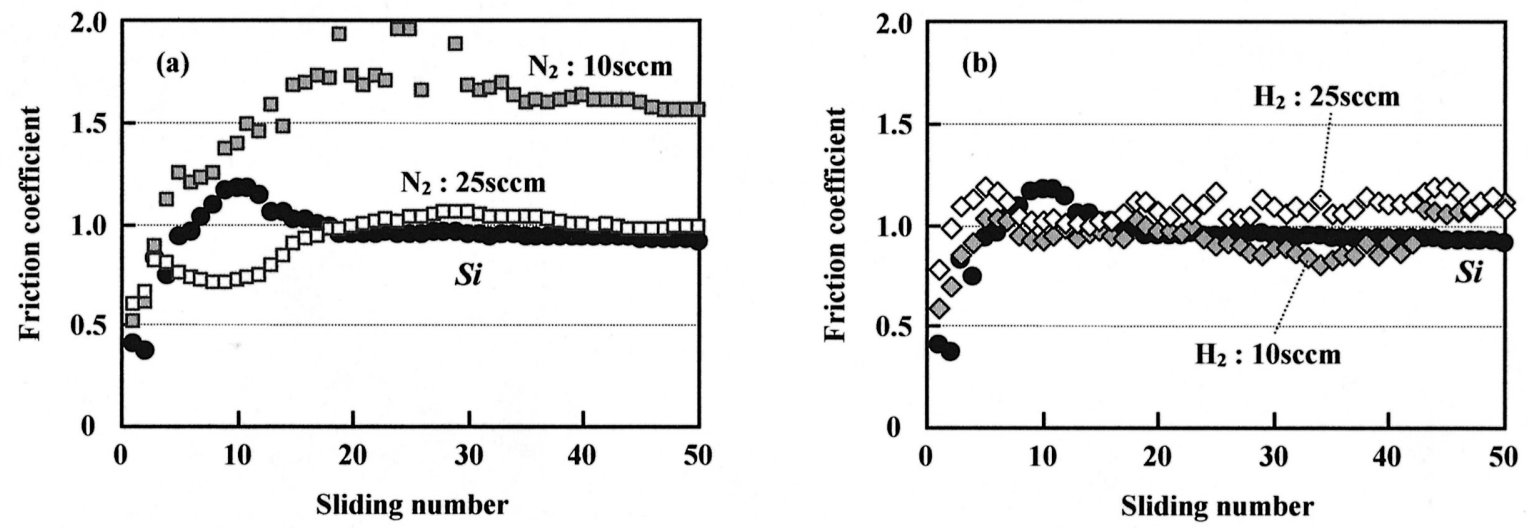

Fig.8 Friction coefficients of Si substrate and $\mathrm{B}_{4} \mathrm{C}$ films (a) prepared with $\mathrm{N}_{2}$ introduction, (b) with $\mathrm{H}_{2}$ introduction

だ十分ではなく, 摩擦試験時に一部剥離した.このことが, $\mathrm{Si}$ と同程度の摩擦特性を示した一因と推測される. また, 剥離量 が僅かな場合でも低摩擦を示さなかったことから，今回得られ た薄膜は本質的にダイヤモンドライクカーボンのような低摩擦 特性を有するものではないと考えられ, 組成の制御を含めた低 摩擦化の検討が今後必要である.

\section{4. 結言}

B-C-N 三元系新規硬質材料の創成を念頭に置き, ホウ素含有 薄膜形成時に反応ガスとして $\mathrm{N}_{2}$ ガスあるいは $\mathrm{H}_{2}$ ガスを添加し た. この反応ガス添加による化学的結合状態の変化を調べ, そ の化学的結合状態の変化がホウ素含有薄膜の密着力を中心とし た機械的特性に及ぼす影響を評価した．その結果，以下のこと が明らかとなった。

1）今回の実験においては, いずれの条件で成膜したホウ素含 有薄膜も非晶質であった.

2) 成膜時に $\mathrm{N}_{2}$ ガスを導入することにより六方晶 $\mathrm{BN}$ に近い 化学結合状態が形成され, 高硬度化に有効である立方晶 BN 構造は創成されなかった. 一方, $\mathrm{H}_{2}$ ガスを導入した場合に は $\mathrm{B}_{4} \mathrm{C}$ 的な結合が維持された.

3) $\mathrm{Ar}$ ガスのみで形成した非晶質 $\mathrm{B}_{4} \mathrm{C}$ 薄膜の微小硬度は $31 \mathrm{GPa}$ と高かった. それに対し, いずれの反応ガスを導入 した場合もホウ素含有薄膜の微小硬度は低下したが, $\mathrm{H}_{2}$ ガ ス導入においては硬度低下の程度が小さかった.

4）いずれの反応ガスを導入した場合も薄膜の密着力の指標と なる臨界荷重は 5 倍以上向上した.

5）反応ガス添加によるホウ素含有薄膜の摩擦特性改善の効果 は得られなかった。

今後, 薄膜中の水素含有量を正確に定量する必要があるが, 今回の結果からは $250^{\circ} \mathrm{C}$ 以下の低温成膜では, 窒素添加に比べ 水素添加の方がホウ素含有薄膜の機械的特性, 特に高硬度特性 を維持したまま密着力を向上させる効果が高いと考えられる. ただし, 現時点のホウ素含有薄膜の密着力は, 切削工具や摺動 部品への応用を考えた場合, まだ十分なレベルには達していな い. 今後, 結晶性ホウ素含有薄膜が得られる条件を見出すこと により, 窒素添加および水素添加の効果が明確になり, より高 硬度で高い密着力を有するホウ素含有薄膜が創成されるものと 期待される.
謝 辞

本研究の一部は, 大澤科学技術振興財団平成 16 年度研究助成 を受けて行ったものである.

また, 本研究を進めるに当たり, XPS 分析においては日新電 機株式会社の, また, 微小硬度測定においては株式会社エリオ ニクスの多大なるご協力を得たことについて，ここに感謝の意 を表し，深く御礼を申し上げます。

\section{参 考 文 献}

1) D. C. Reigada, R. Prioli, L. G. Jacobsohn and F. L. Freire Jr.: Boron carbide films deposited by a magnetron sputter-ion plating process: film composition and tribological properties, Diamond Relat. Mater., 9, (2000)489.

2) M.L. Wu, J. D. Kiely, T. Klemmer, Y.-T. Hsia and K. Howard: Process-property relationship of boron carbide thin films by magnetron sputtering, Thin Solid Films, 449, (2004)120.

3) A. Y. Liu and M. L. Cohen: Prediction of new low compressibility solids, Science, 245, (1989)841.

4) A. Y. Liu and M. L. Cohen: Structural properties and electronic structure of low-comperssibility materials: $\beta-\mathrm{Si}_{3} \mathrm{~N}_{4}$ and hypothetical $\beta-\mathrm{C}_{3} \mathrm{~N}_{4}$, Phys. Rev. B, 41, 15, (1990) 10727.

5) J. Robertson: Deposition mechanism of cubic boron nitride, Diamond Relat. Mater., 5, (1996)519.

6) T. Yoshida: State-of the-art vapor-phase deposition of cubic boron nitride, Diamond Films and Technol., 7, 2, (1997)87.

7) M. Kohzaki, A. Matsumuro, T. Hayashi, M. Muramatsu and K. Yamaguchi: Influence of deposition temperatures on bonding state and microstructure of carbon nitride thin films prepared by ion-beam-assisted deposition, Jpn. J. Appl. Phys., 36, 4A, (1997) 2313.

8）神崎昌郎, 松室昭仁, 村松睦夫, 林敏行, 山口勝美: イオンビーム 支援蒸着法による窒化炭素膜形成における $\mathrm{Ar}$ イオン添加の効果, 精 密工学会誌, 64, 1, (1998) 152 .

9) A. Lousa, J. Esteve, S. Muhl, E. Martínez: BCN thin films near the $\mathrm{B}_{4} \mathrm{C}$ composition deposited by radio frequency magnetron sputtering, Diamond Relat. Mater., 9, (2000)502.

10) T-S. Yang, T-H. Tsai, C-H. Lee, C-L. Cheng, M-S. Wong: Deposition carbon-containing cubic boron nitride films by pulsed-DC magnetron sputtering, Thin Solid Films, 398-399, (2001) 285.

11) P. B. Mirkarimi, K. F. McCarty, D. L. Medlin, W. G. Wolfer, T. A. Friedmann, E. J. Klaus, G. F. Cardinale and D. G. Howitt: On the role of ions in the formation of cubic boron nitride films by ion-assisted deposition, J. Mater. Res, 9, 11, (1994)2925.

12) W. J. Pan, J. Sun, H. Ling, N. Xu, Z. F. Ying and J. D. Wu: Preparation of thin films of carbon-based compounds, Appl. Surf. Sci., 218, (2003)297.

13) E. Pascual, E. Matínez, J. Esteve and A Lousa: Boron carbide thin films deposited by tuned-substrate $\mathrm{RF}$ magnetron sputtering, Diamond Relat. Mater., 8, (1999) 402.

14) $\mathrm{M}$. Kawaguchi: $\mathrm{B} / \mathrm{C} / \mathrm{N}$ materials based on the graphite network, Adv. Mater., 9, 8, (1997)615. 